\title{
Cost-effective plantlet production and wintering method of virginia fanpetals (Sida hermaphrodita L. Rusby)
}

\author{
Kurucz, E., ${ }^{1}$ Antal, G., ${ }^{1}$ Popp, J. $^{2}$ \& Fári, M. G. ${ }^{1}$ \\ ${ }^{1}$ Department of Agricultural Botany, Plant Physiology and Plant Biotechnology, University of Debrecen, \\ Hungary; \\ ${ }^{2}$ Faculty of Applied Economics and Rural Development, University of Debrecen, Hungary. \\ (era.kurucz@gmail.com)
}

\begin{abstract}
Summary: The main goal of this research was to work out programmable, cost-effective and industrial scale technologies of mass propagation from the seeds of rootstock nurseries of undomesticated American populations of Sidahermaphrodita. During our previou`s seed treatment experiments, it was concluded that around $60 \%$ of the Virginia fanpetalsseeds collected during the four cropyears can be considered as high quality, infection-free, normally imbibing and germinating seeds (Kurucz et al., 2013a,b). The experiments performed with the nurse-in-tray method developed by us showed that the summer-autumn nurse-in-tray plantlet production and unprotected wintering of Virginia fanpetals with properly pre-treated and fractioned seeds is a promising new method. No weeds appear between the plants, but only on the side of the cases during plantlet production. The investment cost of the method is minimal. There are no heating costs and this phytotechnique can be easily and properly mechanised. Plantlet production can be performed near the large-scale plots. After exploring the root and shoot system, it was concluded that the nurse-in-tray method is suitable for producing plantlets with hardened and strong roots. Scheduled plantlets can be produced in an industrial scale volume by the time of early spring (March) plantlet planting. The excavateof plantlets can be flexibly adjusted to the needs; they may even grow in the plantlet cases for a whole year. We think that these innovative plantlet production and wintering methods which are suitable for large-scale use will make Virginia fanpetals a proper feedstock for the constant supply of the Biomass Supply Chain both in Hungary and in European countries which are in the same climate zone. The comparative analysis of the costs of this procedure calls for further research.
\end{abstract}

Keywords: Sidahermaphrodita Rusby, Virginia fanpetals, plantlet production, nurse-in-tray method

\section{Introduction}

Global energy demand is increasing, as is the environmental damage due to fossil fuel use. Continued reliance on fossil fuels will make it very difficult to reduce emissions of greenhouse gases that contribute to global warming. Bioenergy currently provides roughly $10 \%$ of global supplies and accounts for roughly $80 \%$ of the energy derived from renewable sources]. The "new" renewables (e.g., solar, wind, biofuel) have been growing fast from a very low base. Althoughtheir contribution is still a marginal component of total global renewable energy supply, they are continuously growing. The global potential for biomass energy production is large in absolute terms, but it is far not enough to replace the current energy usage. Increasing biomass energy production beyond a certain level would have significant effects on land use and conventional agricultural markets. Use of cellulosic feedstocks which originate from production systems that tend to have less land-use related greenhouse gas emissions (for example marginal land) offer greater potential for greenhouse gas mitigation (Popp et al., 2014).

In the EU bioenergy should be produced in line with EU objectives to use resources more efficiently. This means reducing the land and other resources needed to produce each unit of bioenergy and avoiding environmental harm from bioenergy production. The most efficient energy use of biomass is for heating and electricity as well as advanced biofuels, also called second generation biofuels. First generation transport biofuels, for example, biodiesel based on oilseed rape or ethanol from wheat/maize, are far less efficient use of resources. The current energy crop mix in the EU is not favourable to the environment, a broader mix of crops could reduce environmental impacts. For example, perennial crops (energy grasses or short rotation willow plantations) would enhance ecosystem services provided by farmland - such as flood prevention and water filtration (Popp et al., 2014) in addition some biomass (second generation) species have remedial effect on the polluted soil, for example gigant red (Arundodonax) on the hevy metal pollution (Ashaal et al 2013).

Virginia fanpetals was first tested as biomass feedstock for energetic purposes 50 years ago in Poland (Borkowska\&Styk, 2006; Szyszlak-Bargowicz, 2012). Dr. Zoltán Kováts, ornamental plant breeder of the Research Institute for Fruit and Ornamental Plants brought Virginia fanpetals to Hungary for the first time in the 1970s during a botanical garden seed exchange by means of accidental mixing up (Kurucz et al., 2012). From ourprevious study, it could be summarized that, 
the new industrial tray method of Sida from special treated seeds is a new possibility to propagate it (Kurucz \& Fári 2013 a,b).

Based on the our previously unpublished research and the experiments carried out so far, researchers list the following main aspects as the production values of growing Virginia fanpetals as a biomass target crop for example, its biomass yield reaches 10-15 absolutely dry ton ha $^{-1}$ year $^{-1}$ (Wróblewska, 2009), it is a favourable characteristic that the moisture content of the stem decreases below $40 \%$ by the end of November; therefore, harvesting can be started at the beginning of winter, e.g. by chipping without artificial desiccation (Kasprzyk, 2014), high winter-tolerant (tolerates snowless winters with temperatures below minus $20 \mathrm{C}^{\circ}$ ) (Borkowska\&Molas 2011), tolerates summer drought (if yearly precipitation reaches 400-500 mm), no special soil preference (Spooner et al., 1985), develops well in light soil treated with wastewater, in addition it able to take up certain heavy metal pollutions from the soil (Borkowska\&Wardzińska, 2003), it can be used as a bee pasture plant (flowering takes place between June and November, depending the the date of first chills)ect. In addition its favourable nutritional values, $\mathrm{C} / \mathrm{N}$ ratio and tissue structure of the stem potentially make it suitable for various energetic uses (Dominguez-Muñoz, 2010; Oleszek el al., 2013).

In our opinion, the main practical objective is to work out a uniform, safe and most importantly cost-effective industrial scale technology of propagation and plantlet production from the seeds of rootstock nurseries of undomesticated American populations. We are certain that further research will result in the economical and cost-effective propagation of this species by the off-season utilisation of existing plantlet production plants in the summer and autumn without heating. Furthermore, it is important to find the proper biologicalphytotechnical solution for the early spring establishment of the plantation instead of the unfavourable, dry late spring and summer seasons. This would make it possible for the population to grow faster during the first year and soil coverage would also be provided. The plantlets costeffectively pre-cultivated and hardened during the previous year are the most suitable for this purpose. Based on the above written points, the aim of our innovative research discussed in this paper was to implement five partial tasks as follows:

- Cost-effective late summer - autumn nurse-in-tray plantlet production of SidahermaphroditaRusby;

- Cost-effective wintering of SidahermaphroditaRusby nurse-in-tray plantlets;

\section{Materials and methods}

\section{Materials and methods of nurse-in-tray plantlet production}

The population of Virginia fanpetals that ismaintained in the Demonstration Garden of the University of Debrecen.
The seed was provided to us by this population and the seeds were colected and cleaned by hand.

Table 1 shows the detailed information about the nurse in tray method requirements.Single space propagation trays were used during the plantlet production experiment (Figure 1).(29 ${ }^{\text {th }}$ June 2013) .A thin layer of pine bark mulch was spread under the soil mixture (Figure 1). Also, a $60 \mathrm{x}$ $60 \mathrm{~cm}$ foil was placed between the soil mix and the tray in order to be able to remove the soil mixture interwoven with roots in one unit at the time of planting the plantlets (Figures 1 and 2). We examined the germination rate of seeds during the experiment, against the time which passed since the treatment. Therefore, two other parameters were added to the experiment during which one part of the seeds were subjected to the two-step seed treatment 30 days before sowing and the other part was treated one day before sowing. The germination percentage of the trays was recorded three weeks after sowing, taking double sown seeds into consideration. Thus, the plantlets were grown in an easilyestablishableopen field space shaded from above and covered with agrotextile. After three weeks, the plantlets were planted into specially prepared $10 \mathrm{~cm}$ deep, $1.5 \mathrm{~m} \times 1.5 \mathrm{~m}$ field cases for planletand they stayed there for wintering, too.

Table 1: Details of the materials requirements of the Nurse in tray method

\begin{tabular}{|l|l|c|c|c|c|}
\hline $\begin{array}{c}\text { Tray } \\
\text { space }\end{array}$ & \multicolumn{1}{|c|}{ Media } & $\begin{array}{c}\text { Amount } \\
\text { used of } \\
\text { Media(I) }\end{array}$ & $\begin{array}{c}\text { Replica- } \\
\text { tions }\end{array}$ & $\begin{array}{c}\text { Density } \\
\text { (space for } \\
\text { seeds/ } \\
\text { tray)* }\end{array}$ & $\begin{array}{c}\text { Other } \\
\text { materials } \\
\text { used }\end{array}$ \\
\hline $\begin{array}{l}1: 1 \text { mixture } 60 \\
\text { of low } \\
\text { divided } \\
\text { nutrient } \\
\text { content field } \\
\text { soil and } \\
\text { commercially } \\
\text { available } \\
\text { medium } \\
\text { nutrient } \\
\text { content soil }\end{array}$ & 20 & 4 & 40, & $\begin{array}{l}\text { pine bark } \\
\text { mulch } \\
60 \times 60 \\
\text { cm foil }\end{array}$ \\
\hline
\end{tabular}

*two seeds were sown in one place again

\section{Methods of the wintering of nurse-in-tray plantlets}

The wintering of nurse-in-tray plantlets was done in field conditions. The four-week-old plants were planted in the Biomass Demonstration Garden of the University of Debrecen on $30^{\text {th }}$ August 2013. We used the foil to removethe soil blocks densely interwoven with roots. After all these blocks were placed in a $1.5 \mathrm{~m} \times 1.2 \mathrm{~m}$ planting trench in one unit, planting the trays of different densities in separate trenches (Figure 2/A). The starting of planted plantlets was surveyed on two occasions, at the time of planting $\left(30^{\text {th }}\right.$ August 2013) and on $21^{\text {st }}$ October 2013 and we made the visual assays every month during the experiment, as the photos of Figure 2 shows. 


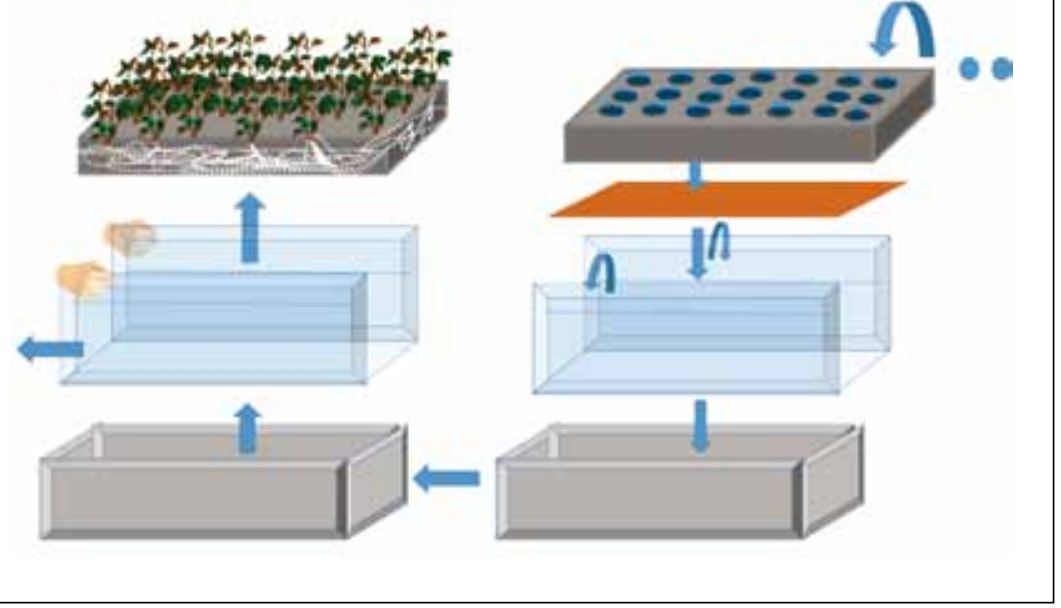

Figure 1. Diagram of nurse-in-tray plantlet production. (Explanation provided in the text.)
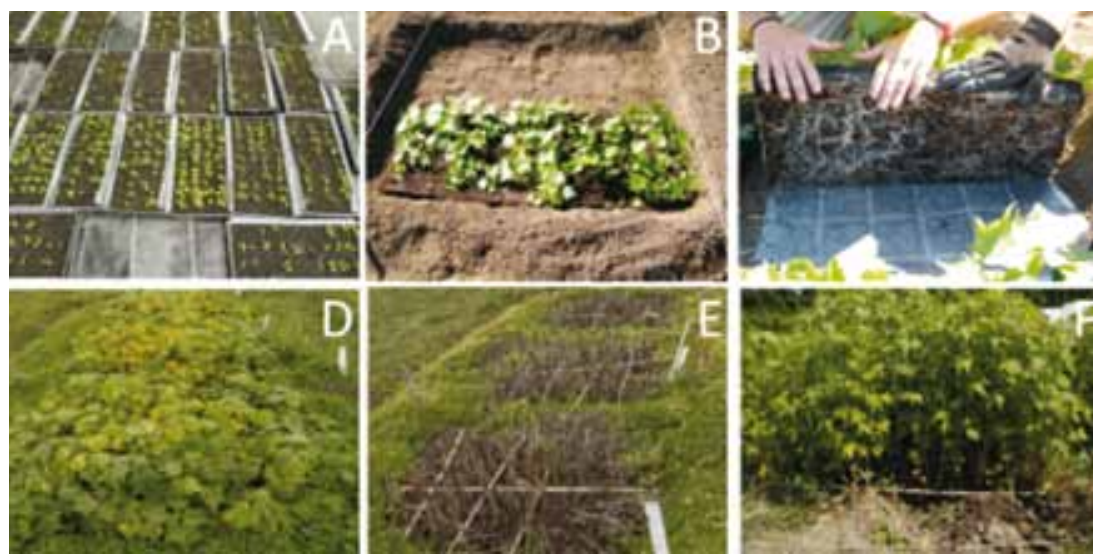

Figure 2. Process of the nurse-in-tray plantlet production of Sida hermaphrodita Rusby. A: 1 week after sowing (05/08/2013) in different densities. B: $1.5 \mathrm{~m}$ x $1.2 \mathrm{~m}$ experimental planting trenches (29/08/2013). C: soil mixture interwoven with the four-week-old plantlets, removed from the nurse-in-tray (30/08/2013). D: four-month-old population (10/12/2013). E: Sevenmonth-old population, before shooting (10/03/2014); F: Ten-month.old plants (28/05/2014) earlier treated seeds, in the case of all plant density. As for treatments marked with 1 , seed treatment was performed 30 days before sowing and the germination rate was between $24.33 \%$ and $30.8 \%$ in the case of number 2 treatment the germination percentage was 50.8 and 64.5. The proportion of double sprouted seeds can still be considered low (less than 20\%). It is worth mentioning that the most efficient plant density was shown to be 40 plant propagation boxes in the case of freshly treated seeds $(64.5 \%)$ and 50 pant per tray. In other cases the plant density had not influence significantly on the germination percent This experiment confirmed our previous hypothesis that the summerautumn nurse-in-tray plantlet production of Virginia fanpetals can be performed with properly pre-treated and fractioned seeds. The comparative analysis of the costs of this procedure calls for further research.

\section{Uncoveredwintering of fieldnurse- in-trayplantlets}

The soil of the plantlets that were planted on 30 August 2013 was weedless until winter because the soil mixture that was used for sowing did not contain any weed seeds

It was observed that the growth of spring field weeds started only on the sides of the cases and no weeds were grown from the bottom, similarly to the autumn. During the winter, $5-10 \mathrm{~cm}$ snow covered the cases on two occasions and winter precipitation was

\section{Statistical analysis}

Descriptive statistical methods (sum, mean, standard deviation) and one-way ANOVA were used to determine the impact of treatments. Data were evaluated with PSPP. The significant differences between each treatment were determined with Tukey's test at the probability level of 5\%.

\section{Results}

\section{Nurse-in-trayplantletproduction}

Figure 3. shows the sharp difference between the efficiency of seed treatment performed at different times. It can be observed that the germination rate of freshly treated seeds was signifikatly higherthan

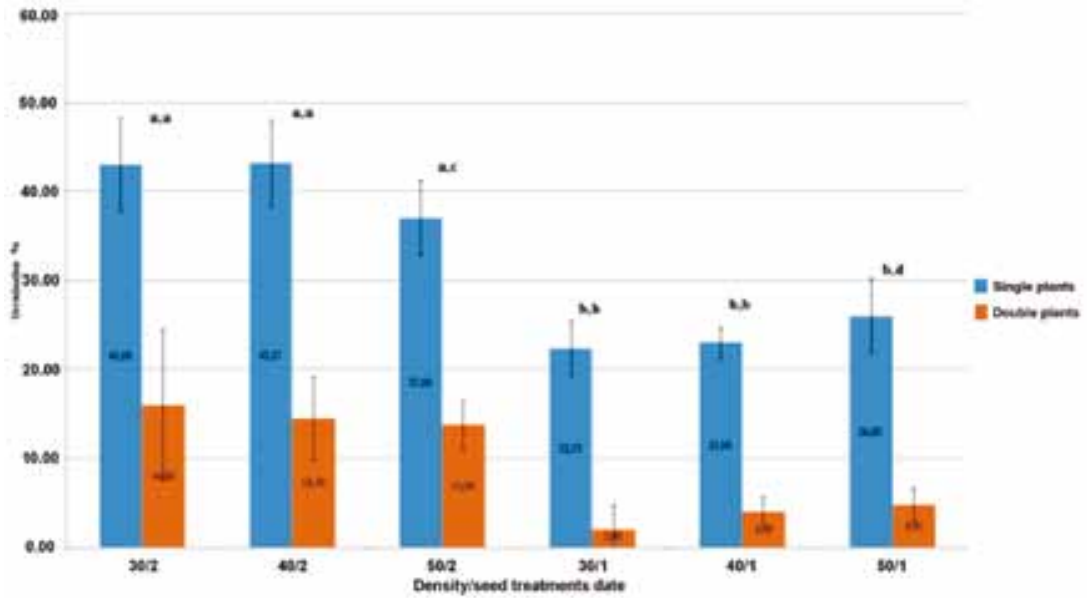

Figure 3. Percentage of germination of Sida hermaphrodita Rusby seeds treatment performed at different times. The different letters show the significant differences with Tukey's test. Letters on the left: impact between the two treatment dates. Letters on the right: differences between the different spacings.

1: treatment was carried out 30 days before the showing.

2: freshly treated seeds 
falling on the wintering plantlets without any external protection. Based on the data of Table 2.we can conclude that the survival rate after wintering was higher in plots with smaller spacing, also considering the fact that the trays in the second treatment had a higher germination rate, resulting in higher plant density. Based on the data of Table 2 , it can be concluded that the individuals of more densely sown trays had a higher plant mortality rate $(55.45 \%$ and $43.48 \%)$, than less denselysownindividuals (29.1$41.9 \%$ ). Consideringall indexes, itcan be es tablished that themoderatelydensesowing (200-220 plantlets per $\mathrm{m}^{2}$ or 40 plantlets per propagationtray) of freshlytreatedseeds is the most successfulmethod.With this procedure, the amount of propagation material needed to plant one hectare (10 000 plantlets per hectare) can be produced on nearly 70 $\mathrm{m}^{2}\left(68.2 \mathrm{~m}^{2}\right)$, as opposed to previously treated seeds in which case this area is larger than $100 \mathrm{~m}^{2}$ $\left(158.18 \pm 25.34 ; 139.35 \pm 37.19 ; \quad 104.07 \pm 10.87 \quad \mathrm{~m}^{2}\right)$.This experiment certified our previous hypothesis that the summerautumn nurse-in-tray plantlet production and unprotected wintering of Virginia fanpetals with properly pre-treated and fractioned seeds can be developed into an economical and safe new method if further research is carried out.

\section{Conclusion}

The practical aim of this study is to find a programmable and cost-effective plantation method of Virginia fanpetals, a promising subshrub which is still at the early stage of domestication. The nurse-in-tray plantlet production is a novel method even on the international scale; this innovative method was developed and first used by our research group.

Our experiments of plantlet production of Virginafanpetals (Sidahermaphrodia) development showed that it is possible produce high quality Virginia fanpetalsplantlets in a programmable and cost-effective way at various times of the year with these new methods, as opposed to the scientific communication in the Polish and Hungarian technical literature. Based on the observations obtained with our current research, we plan to study the cost and income relations of the newly developed plantlet production techniques based on detailed economic data in the near future, thereby facilitating the decision-making of policymakers and economic actors interested in the introduction of Virginia fanpetals. We belive that this costeffective methods can successfully contribute to avoid serious agrotechnical limiting factors and extra costs which were characteristic of previously used technologies, such as spring mechanical sowing in the field.

\section{Acknowledgements}

This research wassupportedby the European Union and theState of Hungary, co-financedbythe European SocialFundin theframework of TÁMOP 4.2.4. A/2-11-12012-0001 'National Excellence Program'.

\section{References}

Alshaal, T., É. Domokos-Szabolcsy, L. Márton, M. Czakó, J. Kátai, P. Balogh, N. Elhawat, H. El-Ramady \& M. Fári (2013): Phytoremediation of bauxite-derivedred mud by giant reed (Arundo donax L.). Journal Environmental Chemistry Letters

Borkowska H. \& Molas R. (2011): Two extremely differentcrops, Salix and Sida, assources of renewablebioenergy. Biomass and Bioenergy. 46: 234-240.

Borkowska, H. \& Styk, B. (2006): Virginia fanpetals (Sidahermaphrodita Rusby) - cultivation and use. WAR, Lublin, pp. 69 (In Polish).

Borkowska, H. \& Wardzińska, K. (2003): Someeffects of Sidahermaphrodita R. cultivationonsewagesludge. Polish Journal of Environmental Studies. 10: 119.

Chudzik B., Szczuka E., Domaciuk M. \& Danail, P. (2010): The structure of theovule of Sidahermaphrodita(L.) Rusbyafterpollination. ActaAgrobotanica, 63 (2), 3-11.

Domìnguez-Muñoz F., Anderson B., Cejudo-Lòpez J. \& Carrillo-Andrès A. (2010), Uncertainty in thethermalconductivity of insulationmaterials, Energy and Buildings, 42: 2168.

Kasprzyk A., Leszczuk A. \& Szczuka (2014): Virginia Mallow (Sidahermaphrodita (L.) Rusby)- Properties and Application Modern Phytomorphology. 6: 91.

Kurucz E., Szarvas P. \& Fári M. G. (2012): Az amerikai bársonymályva (Sidahermaphrodita L. Rusby), mint mérsékelt égövi cserjepótló mályvaféle többcélú hasznosításának lehetőségei (Alternatives of themultipleuse of Virginia mallow (Sidahermaphrodita L. Rusby). Acta Agraria Debreceniensis, 46: 51-57. 
Kurucz, E. \& Fári, M.G. (2013a): Relation between the germination and infection ratio on Sidahermaphrodita L Rusby seeds under hotwater treatment. International Journal of Horticulture Sciences. 19 (1-2): 117-121.

Kurucz E. \& Fári, M.G. (2013b): Improvement of germination capacity of Sidahermaphrodita (L.) Rusbybyseed primingtechniques. International Review of AppliedSciences and Engineering, 4 (2): 137-142.

Oleszek M., Matyka M., Lalak J.,Tys J. \& Paprota E. (2013): Characterization of Sidahermaphroditaas a feedstockforanaerobicdigestion process. Journal of Food, Agriculture \& Environment, 11 (3-4): 1839-1841.

Popp J., Lakner Z., Harangi-Rákos M. \& Fári M. (2014): The effect of bioenergyexpansion: Food, energy, and environment:
Renewable and Sustainable Energy Reviews, 32: 559-578. http:// dx.doi.org/10.1016/j.rser.2014.01.056

Spooner, D.M., Cusick, A.W., Hal, I. G.F \& Baskin, J.M. (1985): Observationsonthe distribution and ecology of Sidahermaphrodita (L.) Rusby (Malvaceae). Sida Contrib. Bot. 11 (2): 215-225

Szyszlak-Bargowicz J., Zajc G. \& W. Piekarski (2012): Energybiomass characteristics of chosenplants Int. Agrophys., 26: 175-179

Wróblewska H., Komorowicz M., Pawłowski J. \& Wojciech C. (2009): Chemical and energeticalproperties of selectedlignocellulosicraw materials. [In FOLIA Forestali APOLONICA Series B, Issue] 40: 67-78. 